\title{
Carbon allocation, nodulation, and biological nitrogen fixation of black locust (Robinia pseudoacacia L.) under soil water limitation
}

\author{
D. Mantovani, M. Veste, K. Boldt-Burisch, S. Fritsch, L.A. Koning, D. Freese
}

Mantovani D., Veste M., Boldt-Burisch K., Fritsch S., Koning L.A., Freese D., 2015. Carbon allocation, nodulation, and biological nitrogen fixation of black locust (Robinia pseudoacacia L.) under soil water limitation. Ann. For. Res. 58(2): 259-274.

Abstract. The pioneer tree black locust (Robinia pseudoacacia L.) is a drought-resistant tree and, in symbiosis with Rhizobium, able to fix dinitrogen from the atmosphere. It is, therefore, an interesting species for marginal lands where soil amelioration is sought in addition to economic gain. However, the interaction between soil water availability, carbon allocation and nitrogen fixation is important for a successful establishment of trees on marginal lands and has not yet been investigated for black locust. Twoyear-old trees were grown under various soil water conditions and drought cycles. The stable isotopic composition of $\mathrm{C}\left(\delta{ }^{13} \mathrm{C}\right)$ and $\mathrm{N}\left(\delta{ }^{15} \mathrm{~N}\right)$ of the leaves was used to identify i) the effective drought condition of the treatments and ii) the portion $\mathrm{N}$ accrued from the atmosphere by the biological nitrogen fixation. Drought-stressed plants significantly reduced their total aboveground biomass production, which was linearly linked to tree transpiration. The shoot:root ratio values changed from 2.2 for the drought-stressed to 4.3 for the well-watered plants. Our investigation shows that drought stress increases the nodule biomass of black locust in order to maintain biological nitrogen fixation and to counteract the lower soil nitrogen availability. The biological nitrogen fixation of drought-stressed trees could be maintained at relatively higher values compared to the well-watered trees. The average leaf nitrogen content varied between $2.8 \%$ and $3.0 \%$ and was not influenced by the drought stress. Carbon fixation, carbon allocation, and biological nitrogen fixation are to some extent balanced at low irrigation and allow Robinia to cope with long-term water constraints. The combination of black locust's ecophysiological and morphological plasticity make it interesting as a biomass source for bioenergy and timber production, even in nutrient-limited and drought-affected areas of Europe. Keywords Rhizobium, water use efficiency, carbon, nitrogen, natural ${ }^{15} \mathrm{~N}$ abundance, drought stress

Authors. Dario Mantovani (mantdar2@gmail.com) - Consiglio per la Ricerca in Agricoltura e l'Analisi dell'Economia Agraria, Via Nursina 2, 06049 - Spoleto. Maik Veste, Katja Boldt-Burisch, Simone Fritsch, Dirk Freese - Brandenburg University of Technology Cottbus-Senftenberg, Chair of Soil Protection and Recultiva- 
tion, Konrad-Wachsmann-Allee 6, 03046 Cottbus, Germany; Laurie Anne Koning - University of Rostock, Crop Health, Satower Straße 48, 18059 Rostock, Germany. Manuscript received May 06, 2015; revised June 26, 2015; accepted July 03, 2015; online first July 27, 2015.

\section{Introduction}

Black locust (Robinia pseudoacacia L.) is one of the few tree species in Europe able to fix atmospheric nitrogen and as a pioneer tree it grows naturally in clear-felled areas (Boring and Swank 1984). More than 350 years ago the tree was introduced from North America as an ornamental garden tree, and later as a forest tree for timber production and as a honey plant for bees in forests. Nowadays, Robinia pseudoacacia is widely distributed in Central, Eastern and South-eastern Europe in various short-rotation forests (Grünewald et al. 2009, Enescu \& Dânescu 2013, Rédei et al. 2014) as well as in urban and human-disturbed landscapes (Sukopp 2004, Cierjacks et al. 2013). Meanwhile, there is an increased interest in black locust plantations for short-rotation forestry and agroforestry on marginal lands where adverse edaphic conditions create prejudice against agricultural production systems (Böhm et al. 2011, Rédei et al. 2014). Interest has also been shown for planting black locust at postmining sites for use in reclaiming ecosystems with pronounced water and nutrient limitations (Dilly et al. 2010, Vlachodimos et al. 2013). The trees are planted in order to enhance soil carbon content (Zeleznik and Skousen 1996, Khan et al. 2010, Matos et al. 2012). In plantations black locust may change the soil nutrient content (Landgraf et al. 2005, Malcolm et al. 2008) and even enhance the nitrogen status of neighboring trees (Lopez et al. 2014). The additional nitrogen input into the ecosystem through the nitrogen fixation of black locust can be considerable with $48-86 \mathrm{~kg} \mathrm{~N} \mathrm{ha}^{-1} \mathrm{a}^{-1}$ (Rice et al 2004, Veste et al. 2013).

Even though the tree originated in climatic regions with annual rainfall of 1020 to 1830 $\mathrm{mm}$, black locust is able to grow in those areas where average annual precipitation is 550-650 $\mathrm{mm}$, in summer the water balance is frequently negative, and drought periods in spring and summer may affect tree growth. On reclaimed post-mining sites in northeastern Germany, where water limitation during the summer months can occur, the biomass production can be considerably high (Böhm et al. 2011) and the good growth performance under extreme soil conditions is explained by its biological nitrogen fixation (Grünewald et al. 2009, Veste et al. 2013). Hence, to deepen our understanding of the growth performance under stress as well as the carbon storage in the ecosystem, an analysis of the carbon allocation is required (Cairns et al. 1997).

The growth performance became particularly important for short-rotation coppices where the aboveground woody biomass of the plant is used periodically and the effective contribution of the root biomass is the major source of uncertainties (Wang et al. 2008). Under resource limitation an optimization of carbon allocation is crucial for growth performance (Bloom et al. 2005, Küppers 1992). The shoot: root ratio is an index to describe the multiple ecophysiological processes involved in carbon portioning and is related to water availability. A well-balanced shoot:root ratio is maintained to ensure water and nutrient uptake for plant growth, but drastic changes in the aboveground or belowground environmental conditions will shift the carbon allocation pattern (Larcher 2003). Mokany et al. (2006) showed in a metaanalysis that the shoot:root ratio in many terrestrial biomes is negatively correlated to the mean annual rainfall and the root biomass 
increases under drought stress. Several works have already been carried out on black locust root vertical distribution analysis and shoot: root ratio (Cheng et al. 2007, Quinkenstein et al. 2011), some of them focusing on the effect of drought on root distribution (Gao et al. 2010, Li et al. 2011).

The importance of the Rhizobia association for the ability of the species to overcome unfavorable soil conditions (Ferrari \& Wall 2007) and soil water limitations (Wurzburger \& Minat 2014) is remarkable for black locust as a pioneer tree (Boring \& Swank 1984). However, the physiological efficiency of the association is influenced by the Rhizobia spp. strain (Batzli et al. 1992). The symbiotic Rhizobium association and the biological nitrogen fixation are sensitive to the soil water availability and drought stress (Schulze et al. 1991, Zahran 1999). Therefore, it is still intensively discussed how drought affects the nitrogen assimilation and biological nitrogen fixation of legumes and the underlying physiological processes and regulations between plant and bacteroids (Serraj et al. 1999, Aranjuelo et al. 2014). In terms of carbon assimilation at the leaf level, the trees have shown a high ecophysiological plasticity and morphological adaptation to cope with drought and high temperature stress (Xu et al. 2009, Veste \& Kriebitzsch 2013).

In a lysimeter experiment the aboveground biomass production of black locust was linearly linked to tree water use and soil water availability; furthermore, the growth performance was influenced by the length of drought cycles (Mantovani et al. 2014 a,b). The question still remains open as to the interaction between aboveground and belowground biomass under water limitation and how the trees can overcome nitrogen limitation in combination with a water constraint. It could be expected that a pronounced water limitation affects root growth and reduces biological nitrogen fixation. Therefore, we aimed to evaluate the impact of drought on carbon allocation, the formation of root nodules and biological nitrogen fixation.

\section{Materials and methods}

\section{Plant material and cultivation}

Two-year-old black locust trees of comparable size (height $279 \pm 42 \mathrm{~mm}$, trunk diameter $16 \pm$ $1 \mathrm{~mm}$ ) and branch architecture were selected from the reclaimed post-mining site in Welzow-Süd (20 km south of Cottbus, Brandenburg, Germany, N 51³6'14", E 14¹9'51'”) in November 2010. After the primary branches were cut back to $100 \mathrm{~mm}$ from the trunk, the plants were placed into $15 \mathrm{~L}$ pots under a rainout shelter to over-winter. In March 2011 six plants were transferred to wicked lysimeters at the Brandenburg University of Technology, Cottbus-Senftenberg. The lysimeters (volume $0.098 \mathrm{~m}^{3}$ ) were filled with sandy loam with a texture of $67.7 \%$ sand, $27.0 \%$ silt, and $5.3 \%$ clay. Soil nitrogen content was $0.6-0.9 \mathrm{~g} \mathrm{~N} \mathrm{~kg}^{-1}$ dry soil and phosphate content was $0.3 \mathrm{~g} \mathrm{P} \mathrm{kg}^{-1}$ dry soil. Every pot received $1.045 \mathrm{~L}$ of a modified Hoagland's solution (without the basic N and P content, Hoagland \& Arnon 1950) for micro-nutrients and $3.18 \mathrm{~g}$ (equivalent to 40 $\mathrm{kg} \mathrm{P} \mathrm{ha}{ }^{-1}$ ) of potassium di-hydrogen phosphate $\left(\mathrm{KH}_{2} \mathrm{PO}_{4}\right)$ as a basic $\mathrm{P}$ fertilizer. No additional $\mathrm{N}$ fertilizer was applied. For further technical details of the lysimeters see Mantovani et al. (2011, 2013).

\section{Irrigation treatments}

The experimental design provided two treatments: high water amount (HW) and low water amount (LW) in relation to the imposed irrigation regimes (Table 1). During the growing season (June $1^{\text {st }}$ to November $8^{\text {th }} 2011$ ) the HW trees were grown constantly at $100 \%$ of the soil water availability (SWA), whereas the LW at $35 \%$ of the SWA, namely, HW-const treatment and LW-const treatment. Throughout the second vegetation period (June $1^{\text {st }}$ until October $\left.11^{\text {th }} 2012\right)$ drought stress cycles (dc) were applied: (i) HW-dc, a short-term stress cycle (one week 35\% SWA and two weeks $100 \%$ 
Table 1 Applied irrigation regime of the different treatments during the experiment in 2011 and 2012. For details see text

\begin{tabular}{|c|c|c|}
\hline Treatment & Irrigation scheme 2011 & Irrigation scheme 2012 \\
\hline \multirow{2}{*}{$\begin{array}{l}\text { HW } \\
\text { (High } \\
\text { water) }\end{array}$} & $\begin{array}{l}\text { HW-const: } \\
100 \% \text { constant }\end{array}$ & $\begin{array}{l}\text { HW-dc:well-watered with short-term drought cycles } \\
(100 \%-35 \%)\end{array}$ \\
\hline & $\begin{array}{l}\text { Cumulative irrigation } \\
0.587 \mathrm{~m}^{3}\end{array}$ & $\begin{array}{l}\text { Cumulative irrigation } \\
0.456 \mathrm{~m}^{3}\end{array}$ \\
\hline \multirow{2}{*}{$\begin{array}{l}\text { LW } \\
\text { (Low water) }\end{array}$} & $\begin{array}{l}\text { LW-const: constant } 35 \%- \\
\text { Vol }\end{array}$ & $\begin{array}{l}\text { LW-dc } \\
\text { constant } 35 \% \text {-Vol }\end{array}$ \\
\hline & $\begin{array}{l}\text { Cumulative irrigation } \\
0.239 \mathrm{~m}^{3}\end{array}$ & $\begin{array}{l}\text { Cumulative irrigation } \\
0.260 \mathrm{~m}^{3}\end{array}$ \\
\hline
\end{tabular}

SWA) starting with a well-watered (100\% SWA) period during the re-sprouting phase (4 weeks), followed by four short-term cycles and (ii) LW-dc, a long-term stress cycle (two weeks $35 \%$ SWA, one week 100\% SWA) starting with four weeks of drought stress $(35 \%$ SWA) at the beginning of the experiment followed by four long-term stress cycles. The total applied irrigation amounts for 2011 and 2012 are shown in Table 1 . The $100 \%$ of the SWA values corresponded to the field capacity of the soil column, where the soil matrix potential $(\psi)$ values were constantly $\mathrm{pF}>-1$. The lower value of $35 \%$ of the SWA is close to the black locust wilting point, with $\psi$ values constantly $\mathrm{pF}<-3$ (for details see Mantovani et al. 2013).

\section{Aboveground biomass}

At the end of the 2011 vegetation period the trees (HW-const and LW-cost) were wrapped in a light-transmissive, polyethylene net before defoliation in order to collect all of the fallen leaves on a daily basis. Once all the leaves had fallen, the branches were cut back to the initial length $(10 \mathrm{~cm})$. For the 2012 experiment wood and leaves of the treatments (HW-dc and LW$\mathrm{dc}$ ) were harvested before defoliation (October $11^{\text {th }} 2012$ ). For the determination of leaf biomass, all of the leaves were oven-dried at $65^{\circ} \mathrm{C}$ until constant weight was reached (both years, 262
2011 and 2012). The biomass of the trunk and the first $10 \mathrm{~cm}$ of the primary branches, which during the 2011 experiment were not harvested, were estimated by multiplying the seasonal volumetric growth increment recorded from the beginning to the end of the experiment with the specific wood density $\left(760 \mathrm{~kg} \mathrm{~m}^{-3}\right)$. The wood density was calculated from a portion of branches with the water displacement method (Olesen 1971). The water use efficiency (WUE) for each vegetation period was calculated for every treatment by the ratio between the total aboveground dry biomass and its cumulative water consumption.

\section{Root biomass and root nodules}

Root sampling was performed at the end of the experiment (October 11 ${ }^{\text {th }}$ 2012) in order to evaluate the vertical spatial distribution of the roots and root nodules and to estimate the belowground biomass. The samples were collected using metal cylinders of $250 \mathrm{~cm}^{3}$ volume ( $8.1 \mathrm{~cm}$ diameter $\mathrm{x} 4.8 \mathrm{~cm}$ length) in three soil depths: (i) 5 to $9.8 \mathrm{~cm}$, (ii) 20 to $24.8 \mathrm{~cm}$, and (iii) 40 to $44.8 \mathrm{~cm}$. For each soil depth, six samples were taken alternatively at $10 \mathrm{~cm}$ and $20 \mathrm{~cm}$ apart from the center of the lysimeter. All the roots and root nodules were separated and soil particles were gently removed from the roots with a paintbrush. Roots were collected with forceps and rotated carefully in a dish of 
water to remove any residual soil. The clean roots were scanned with a flat-bed scanner (Epson Perfection V700 Photo Scanner) with 400 dpi resolution. Root length density and root surface areas density were calculated by using WinRHIZO software (Version 2009, Regent Instruments Inc., Quebec, Canada). After the morphological analyses and classification, roots and nodules were oven-dried separately at $65{ }^{\circ} \mathrm{C}$ until constant weight was reached. The root weight density $\left(\mathrm{kg} \mathrm{m}^{-3}\right)$ was calculated for each sample, obtained by the ratio of the root oven-dried weight and the volume of the soil sampled. In order to estimate the total root biomass, the soil column was divided into three relatively homogeneous layers: (i) from 0 to $16.6 \mathrm{~cm}$ depth, (ii) from 16.6 to $33.3 \mathrm{~cm}$ depth and (iii) from 33.3 to $50 \mathrm{~cm}$ depth. The volume of each layer $\left(0.033 \mathrm{~m}^{3}\right)$ was multiplied with the root weight density evaluated at $5-9.8 \mathrm{~cm}$ depth, 20 to $24.8 \mathrm{~cm}$ depth and 40 to $44.8 \mathrm{~cm}$ depth to estimate total root biomass. The shoot:root ratios were estimated from the shoot dry weight (stem + stump) and the estimated root dry biomass. Since the destructive root sampling was performed only after the two vegetation periods, the analysis here only takes into account the aboveground biomass produced during the vegetation period 2012 .

\section{Leaf isotopic $\mathbf{N}$ composition and leaf $\mathbf{N}$ con- tent}

A mixed sample of 20 leaflets from 20 different fully developed leaves for each tree was collected and oven-dried at $65^{\circ} \mathrm{C}$ until constant weight was reached. For the analysis the dried sample was homogenized and pulverized. The leaf nitrogen content was determined with a CNS-elemental analyzer (Elementar Vario, Elementar Analysensysteme GmbH, Hanau, Germany).

\section{Estimation of the biological nitrogen fixation}

In order to determine the biological $\mathrm{N}_{2}$ fixation of the Robinia-Rhizobium symbioses we used the natural ${ }^{15} \mathrm{~N}$ abundance method (for details see Boddey et al. 2000). The nitrogen isotope fractionations $\left({ }^{15} \mathrm{~N} /{ }^{14} \mathrm{~N}\right)$ were measured with the isotope mass spectrometer Thermo Electron Delta V (Thermo Fisher Scientific Inc., Waltham, MA, USA). The natural ${ }^{15} \mathrm{~N}$ abundances ( $\delta \%$ units) were calculated according to equation 1 :

$\delta \%=\left(\mathrm{R}_{\mathrm{S}}-\mathrm{R}_{\mathrm{o}}\right) / \mathrm{R}_{\mathrm{o}} \cdot 1000$

(eq. 1)

where $R_{S}$ is the ${ }^{15} \mathrm{~N} /{ }^{14} \mathrm{~N}$ ratio of sample and $R_{0}$ is the ${ }^{15} \mathrm{~N} /{ }^{14} \mathrm{~N}$ ratio of atmospheric $\mathrm{N}_{2}$. Because the $\delta^{15} \mathrm{~N}$ signature of nitrogen derived from soil (NdfS) is commonly enriched in comparison to nitrogen derived from the atmosphere (NdfA), this ${ }^{15} \mathrm{~N}$ soil enrichment can be used as a natural tracer (Russow et al. 2004). The NdfA can be calculated using a two-pool model from the quotient of the ${ }^{15} \mathrm{~N}$ abundance of the $\mathrm{N}_{2}$-fixing plant and the soil $\mathrm{N}$ available to the plant. As a reference we used the soil nitrogen pool. Our approach to determine the $\mathrm{N}_{2}$-fixation expressed as nitrogen derived from the air (NdfA) followed the calculation by Russow et al. (2004) and was according to equation 2 :

$\operatorname{NdfA}=\left(\delta_{r}-\delta_{f}\right) /\left(\delta_{r}-\delta_{b}\right) \cdot 100$

where $\delta_{\mathrm{f}}$ is $\delta^{15} \mathrm{~N}$ of $\mathrm{N}_{2}$-fixing plant, $\delta_{\mathrm{r}}$ is the $\delta^{15} \mathrm{~N}$ of reference sample (in this case of the soil) and $\delta_{b}$ is the isotopic shift against air's $\delta^{15} \mathrm{~N}$ signature by the biological nitrogen fixation $(\mathrm{BNF})$ itself. We used as an isotopic shift $\left(\delta_{\mathrm{b}}\right)$ a value of $-1.2 \%$ to avoid an overestimation of BNF. The measured values $\delta^{15} \mathrm{~N}$ of the soils were $+4.63+/-0.22 \%$ and used in equation 2 as the reference $\left(\delta_{r}\right)$. Because the NdfA gives relative values of the $\mathrm{BNF}$, we estimated the absolute nitrogen input fixed by the symbiotic Rhizobium association according to equation 3 (for details see Russow et al. 2008):

$$
\mathrm{BNF}=\mathrm{NdfA} \cdot \mathrm{bm} \cdot \mathrm{N}_{\text {cont }}
$$


where BNF is the absolute nitrogen input by the biological nitrogen fixation, bm the dry leaf biomass of the tree or the dry wood production, and $\mathrm{N}_{\text {cont }}$ the nitrogen content of the leaves or wood. For the wood we used a mean nitrogen content of $1.4 \%$ as determined for black locust in Welzow-Süd (Veste et al. 2013).

\section{Statistical analysis}

Statistical analyses were performed using the IBM SPSS version 21 (SPSS Inc., Chicago,

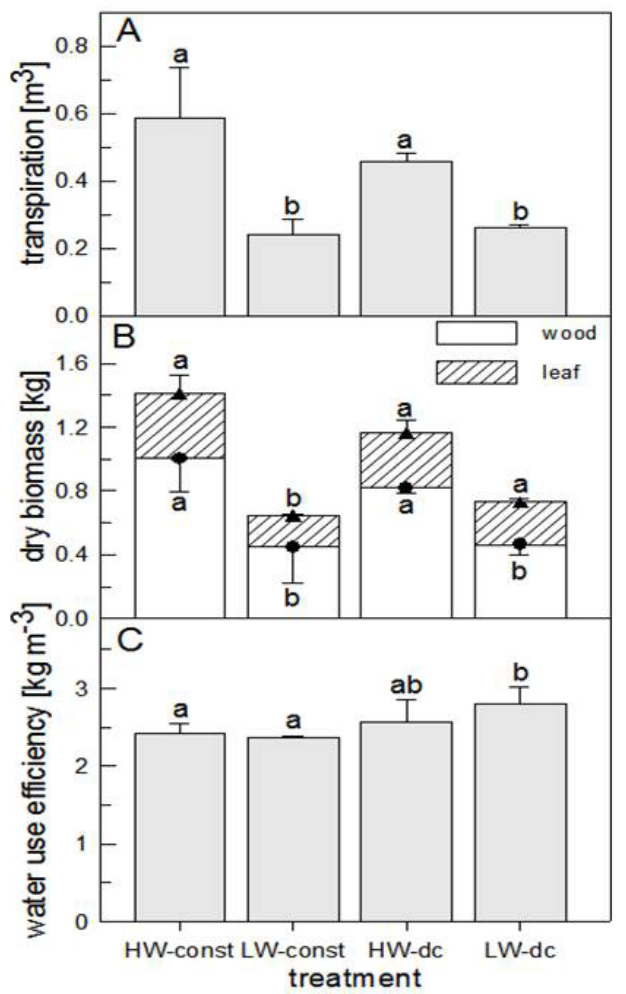

Figure 1 Mean and standard deviations of cumulative transpiration (A), leaf and wood biomass (B) and water use efficiency of Robinia pseudoacacia (C)

2011: HW-const: high water amounts constant, LW-const low water amounts constant, 2012: HW-dc: high water amounts with short-term drought cycles, LW-dc: low water amounts with long-term drought cycles; see text and Table 1 for details. Different letters indicate significant difference $(p<0.05)$.
IL, USA). A non-parametric Mann-Whitney U-Test $(p<0.05)$ was performed to compare the treatments in terms of (i) mean transpiration, (ii) mean dry leaf and wood biomass, (iii) mean root weight density, (iv) mean root length density, (v) mean root surface area density, (vi) mean root dry weight, (vii) root nodule spatial distribution, and (viii) variation in stable isotope $\left(\delta^{15} \mathrm{~N}\right)$ ratio. A Spearman's rho coefficient of correlation $(p<0.05$ and $p<0.01)$ was calculated to relate the depth with (i) the mean root weight density, (ii) the mean of the length density, (iii) the mean root surface, and (iv) the mean root nodule weight density.

\section{Results}

\section{Transpiration, biomass and water use efficiency}

Water constraint affected tree transpiration (Figure 1A) with significant effects on aboveground biomass production in both years of the investigation (Table 2). During the 2011 vegetation period, the LW-const aboveground production was $54 \%$ of the HW-const, while in 2012 the difference between HW-dc and LWdc decreased to $37 \%$ (Figure 1B). The water use efficiency was comparable in 2011 among the HW-const and LW-const treatments with an average of $2.39 \mathrm{~kg} \mathrm{~m}^{-3}$. With the application of drought cycles, the WUE of the trees were slightly higher $\left(2.68 \mathrm{~kg} \mathrm{~m}^{-3}\right)$ than the previous vegetation period (Fig 1c), but the values showed no significant differences between the drought cycles (HW-dc vs. LW-dc).

\section{Biomass allocation}

The variations in woody biomass allocation among the treatments (Table 3) are shown in Figure 2. Significant differences have been recorded for the shoot (stem + stump) biomass between the HW-dc and LW-dc trees at the end of the experiment, while the total root bio- 
Table 2 Mean and standard deviation of the aboveground dry biomass production and water use of Robinia pseudoacacia evaluated during the experiments in 2011 and 2012

\begin{tabular}{lllllllll}
\hline Treatment & $\begin{array}{l}\text { Transpiration } \\
\left(\mathrm{m}^{3}\right)\end{array}$ & $\begin{array}{l}\mathrm{sd} \\
\left(\mathrm{m}^{3}\right)\end{array}$ & $\begin{array}{l}\text { Wood } \\
\text { biomass } \\
(\mathrm{kg})\end{array}$ & $\begin{array}{l}\mathrm{sd} \\
(\mathrm{kg})\end{array}$ & $\begin{array}{l}\text { Leaf } \\
\text { biomass } \\
(\mathrm{kg})\end{array}$ & $\begin{array}{l}\text { sd } \\
(\mathrm{kg})\end{array}$ & $\begin{array}{l}\text { Water use } \\
\text { efficiency }\end{array}$ & sd \\
\hline HW-cost & $0.59^{\mathrm{a}}$ & 0.15 & $1.00^{\mathrm{a}}$ & 0.21 & $0.41^{\mathrm{a}}$ & 0.11 & $2.42^{\mathrm{a}}$ & 0.13 \\
LW-const & $0.24^{\mathrm{b}}$ & 0.04 & $0.45^{\mathrm{b}}$ & 0.23 & $0.20^{\mathrm{b}}$ & 0.01 & $2.37^{\mathrm{a}}$ & 0.03 \\
HW-dc & $0.46^{\mathrm{a}}$ & 0.03 & $0.82^{\mathrm{a}}$ & 0.04 & $0.34^{\mathrm{a}}$ & 0.08 & $2.56^{\mathrm{ab}}$ & 0.30 \\
LW-dc & $0.26^{\mathrm{b}}$ & 0.01 & $0.46^{\mathrm{b}}$ & 0.06 & $0.27^{\mathrm{a}}$ & 0.02 & $2.80^{\mathrm{b}}$ & 0.20 \\
\hline
\end{tabular}

Note. Numbers labeled with the same letters are not significantly different $(p \leq 0.05)$.

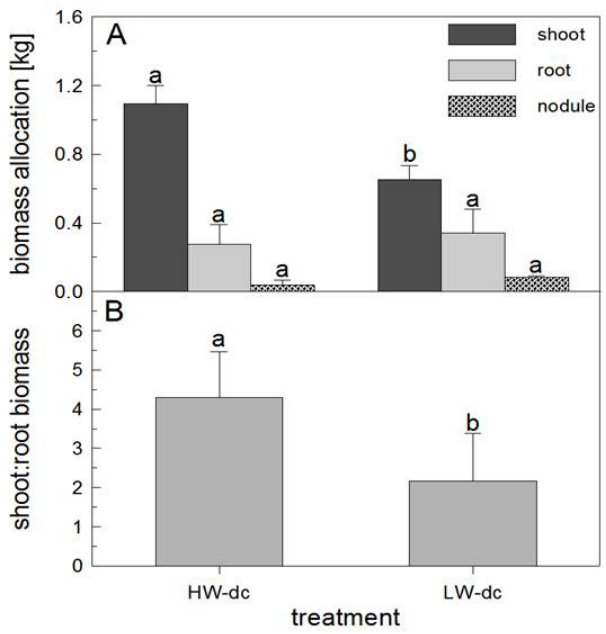

Figure 2 Mean and standard deviations of total aboveground and belowground biomass (A), nodule biomass (B) and shoot:root ratio $(\mathrm{C})$. Trees were harvested at the end of the experiment in September 2012 Different letters indicate significant difference $(p<0.05)$.

masses are comparable (Figure 2A). Under lower irrigation (LW-dc) the shoot:root ratio decreased to 2.2 compared to 4.3 for the well-watered trees (HW-dc) (Figure 2B). It is important to highlight that the total nodule biomass of well-watered trees was only the $64 \%$ compared to the LW-dc (Figure 2A).

\section{Root system and nodules}

The analysis of the root weight density, root surface area and the root length density shows a comparable spatial distribution of the root system along the soil column (Figure 3 ) for both treatments (Table 4). The root nodule weight densities of the LW plants at 5-10 and 20-25 $\mathrm{cm}$ depths (Table 5) were $66 \%$ and $85 \%$ more than those of the HW treatment, respectively (Figure 4A), while the nodule:root weight ratio (Figure 4B) increased with drought stress, although neither of these relationships were shown to be statistically significant.

\section{Leaf nitrogen content and biological nitrogen fixation}

The leaf nitrogen contents were not significantly different between the irrigation treatments (Figure 5A), varying between $2.8 \%$ \pm 0.79 and $3.0 \% \pm 0.17$ (Table 5). The $\delta^{15} \mathrm{~N}$ values of Robinia under the different irrigation regimes are shown in Figure 5B. The lowest values were measured in the well-watered trees (HW-const) and increased under low soil water content (LW-const, LW-dc), whereas trees growing under short-term drought cycles (HW-dc) showed less ${ }^{15} \mathrm{~N}$ enrichment. Due to the soil homogenization procedure, the plants were growing on substrate with a comparable $\mathrm{N}$ stable isotope composition $\left(\delta^{15} \mathrm{~N}_{\text {soil }}=+4.63\right.$ $\%$ \pm 0.22 ). Based on the $\delta^{15} \mathrm{~N}$ values of the soil itself as a reference, the calculated NdfA values (for the leaves) was highest in the trees growing under constant high water supply (HW-const) (Figure 5c). The estimated relative amounts of nitrogen fixed by BNF was $94 \%$ 
Table 3 Mean and standard deviation of the biomass allocation of Robinia pseudoacacia, estimated at the end of the experiment 2012 (October $11^{\text {th }} 2012$ )

\begin{tabular}{lllllllll}
\hline Treatment & $\begin{array}{l}\text { Shoot } \\
(\mathrm{kg})\end{array}$ & $\begin{array}{l}\mathrm{sd} \\
(\mathrm{kg})\end{array}$ & $\begin{array}{l}\text { Root } \\
(\mathrm{kg})\end{array}$ & $\begin{array}{l}\mathrm{sd} \\
(\mathrm{kg})\end{array}$ & $\begin{array}{l}\text { Nodule } \\
(\mathrm{kg})\end{array}$ & $\begin{array}{l}\mathrm{sd} \\
(\mathrm{kg})\end{array}$ & $\begin{array}{l}\text { Shoot/ } \\
\text { root }\end{array}$ & $\mathrm{sd}$ \\
\hline HW-dc & $1.09^{\mathrm{a}}$ & 0.11 & $0.28^{\mathrm{a}}$ & 0.12 & $0.04^{\mathrm{a}}$ & 0.03 & $4.29^{\mathrm{a}}$ & 1.16 \\
LW-dc & $0.65^{\mathrm{b}}$ & 0.08 & $0.34^{\mathrm{a}}$ & 0.14 & $0.08^{\mathrm{a}}$ & 0.01 & $2.16^{\mathrm{b}}$ & 1.22 \\
\hline
\end{tabular}

Note. Numbers labeled with the same letters are not significantly different $(p \leq 0.05)$.

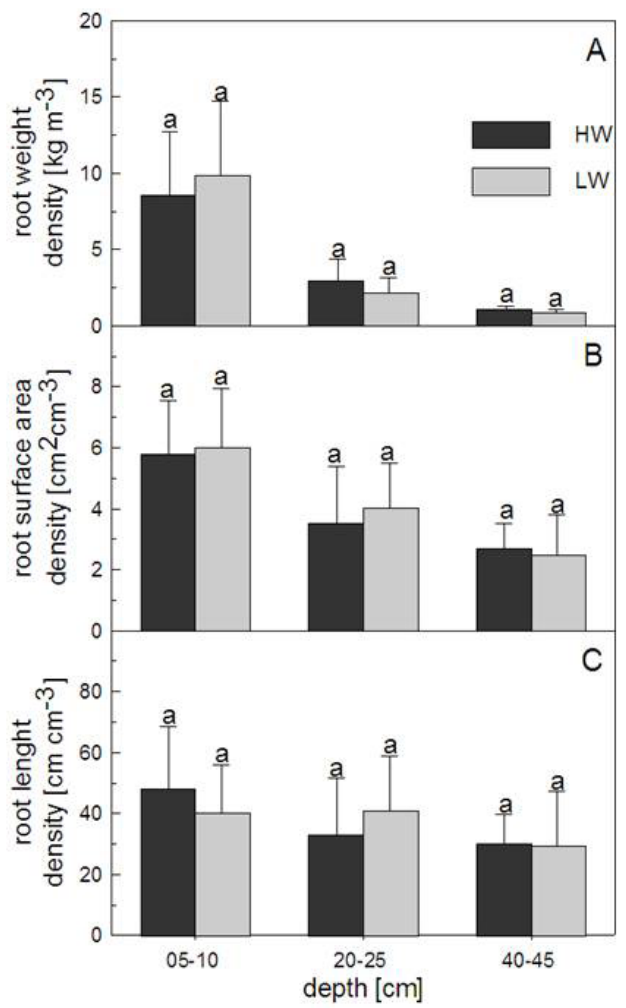

Figure 3 Mean and standard deviation of fine root weight density (dry weight) (A), root surface area density $(C)$, and root length density (B) at different soil layers of Robinia pseudoacacia at the end of the experiment. (October $11^{\text {th }}$ 2012)

Different letters indicate significant difference $(p<0.05)$.

\pm 15 , while under water limitation the relative nitrogen fixation decreased to $82 \%$ for LWconst and $87 \%$ for LW-dc. Under short-term stress drought cycles the BNF was more reduced (Figure 5c), but the differences between the treatments were not significant. Figure 6 shows the total nitrogen amounts fixed by the $\mathrm{BNF}$ in the aboveground biomass. Following the biomass production of leaves and wood (Figure 1B), the highest total nitrogen amounts from the BNF could be found here in well-watered trees (HW-const), while water limitation decreased the total fixed-N by BNF according to the irrigation amounts.

\section{Discussion}

Our investigation into various soil water availabilities clearly showed the growth response of the aboveground biomass to drought stress and its capability to cope with water constraints. The water use efficiency was not changed by the drought stress in both experiments. For broadleaved trees in the temperate zones, Larcher (2003) gives average water use efficiencies of $3-5 \mathrm{~kg} \mathrm{~m}^{-3}$. But, our results in the lysimeter experiments indicate a higher water consumption of black locust compared to other fast-growing trees like willows with a WUE in the range of $5.3-6.3 \mathrm{~kg} \mathrm{~m}^{-3}$ (Lindroth \& Cienciala 1996, Linderson et al. 2007). However, comparable long-term WUE data for trees are rare and often calculated with meteorological methods or extrapolation based on gas exchange measurements.

The adaptations of black locust to the drought stress took place on two levels: (i) morphological adaptations on the plant level and (ii) stomatal control on the leaf level. Trees growing under drought conditions adapted their leaf areas to the soil water availability in order to limit transpiration (Mantovani et al 2014 a,b). In addition, to further limit water loss the sto- 
Table 4 Mean and standard deviation of the root characteristics of Robinia pseudoacacia, evaluated at different soil layers at the end of the experiment 2012 (October $11^{\text {th }}$ 2012)

\begin{tabular}{lllllllr}
\hline \multirow{2}{*}{ Treatment } & $\begin{array}{l}\text { Depth } \\
(\mathrm{cm})\end{array}$ & $\begin{array}{l}\text { Root } \\
\text { weight } \\
\text { density } \\
\left(\mathrm{kg} \mathrm{m}^{-3}\right)\end{array}$ & $\begin{array}{l}\text { sd } \\
\left(\mathrm{kg} \mathrm{m}^{-3}\right)\end{array}$ & $\begin{array}{l}\text { Root } \\
\text { surface area } \\
\text { density } \\
\left(\mathrm{cm}^{2} \mathrm{~cm}^{-3}\right)\end{array}$ & $\begin{array}{l}\text { sd } \\
\left(\mathrm{cm}^{2} \mathrm{~cm}^{-3}\right)\end{array}$ & $\begin{array}{l}\text { Root } \\
\text { length } \\
\text { density } \\
\left(\mathrm{cm} \mathrm{cm}^{-3}\right)\end{array}$ & $\begin{array}{l}\text { sd } \\
\left(\mathrm{cm} \mathrm{cm}^{-3}\right)\end{array}$ \\
\hline \multirow{3}{*}{$\mathrm{HW}$} & $05-10$ & $8.61^{\mathrm{a}}$ & 4.20 & $6.94^{\mathrm{a}}$ & 2.11 & $47.98^{\mathrm{a}}$ & 20.70 \\
& $20-25$ & $2.94^{\mathrm{a}}$ & 1.38 & $4.24^{\mathrm{a}}$ & 2.22 & $32.92^{\mathrm{a}}$ & 18.84 \\
& $40-45$ & $1.05^{\mathrm{a}}$ & 0.23 & $3.24^{\mathrm{a}}$ & 0.97 & $29.90^{\mathrm{a}}$ & 9.86 \\
\hline \multirow{3}{*}{$\mathrm{LW}$} & $05-10$ & $9.88^{\mathrm{a}}$ & 4.90 & $7.21^{\mathrm{a}}$ & 2.32 & $39.97^{\mathrm{a}}$ & 16.16 \\
& $20-25$ & $2.16^{\mathrm{a}}$ & 1.01 & $4.81^{\mathrm{a}}$ & 1.78 & $40.91^{\mathrm{a}}$ & 17.90 \\
& $40-45$ & $0.88^{\mathrm{a}}$ & 0.20 & $2.96^{\mathrm{a}}$ & 1.60 & $29.50^{\mathrm{a}}$ & 17.79 \\
\hline
\end{tabular}

Note. Numbers labeled with the same letters are not significantly different $(p \leq 0.05)$.

Table 5 Mean and standard deviation of the nodules associated with Robinia pseudoacacia roots, evaluated at different soil layers at the end of the experiment 2012 (October 11 ${ }^{\text {th }}$ 2012)

\begin{tabular}{llllll}
\hline Treatment & $\begin{array}{l}\text { Depth } \\
(\mathrm{cm})\end{array}$ & $\begin{array}{l}\text { Nodule weight density } \\
\left(\mathrm{kg} \mathrm{m}^{-3}\right)\end{array}$ & $\begin{array}{l}\text { sd } \\
\left(\mathrm{kg} \mathrm{m}^{-3}\right)\end{array}$ & Nodule/root & sd \\
\hline \multirow{3}{*}{$\mathrm{HW}$} & $05-10$ & $0.95^{\mathrm{a}}$ & 0.94 & $0.14^{\mathrm{a}}$ & 0.10 \\
& $20-25$ & $0.04^{\mathrm{a}}$ & 0.03 & $0.05^{\mathrm{a}}$ & 0.03 \\
\multirow{3}{*}{ LW } & $40-45$ & $0.13^{\mathrm{a}}$ & 0.09 & $0.06^{\mathrm{a}}$ & 0.07 \\
\hline & $05-10$ & $2.16^{\mathrm{a}}$ & 1.13 & $0.25^{\mathrm{a}}$ & 0.13 \\
& $20-25$ & $0.30^{\mathrm{a}}$ & 0.27 & $0.12^{\mathrm{a}}$ & 0.10 \\
\hline
\end{tabular}

Note. Numbers labeled with the same letters are not significantly different $(p \leq 0.05)$.

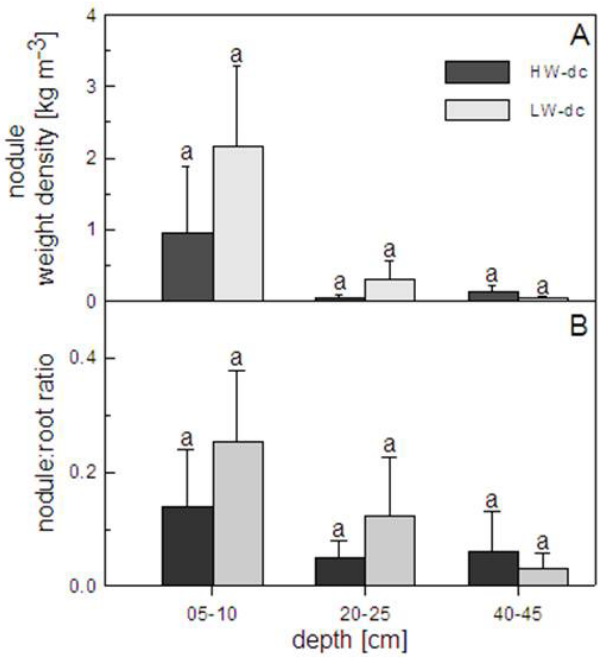

Figure 4 Mean and standard deviation of the root nodule weight density (A) and the nodule:root biomass ratio (B), calculated for different soil layers at the end of the experiment (October $11^{\text {th }} 2012$ ) matal response is observed on drought-stressed trees under higher water vapour deficits (Mantovani et al. 2014a). Especially in the second experiment (2012), the long-term drought stress affected the stomata opening as indicated by the measured differences in the $\delta^{13} \mathrm{C}$ isotopic composition. For the LW- dc trees $\delta^{13} \mathrm{C}$ values of $-26.2 \% \pm 0.17$ were measured, while the HW-dc trees had values of -28.03 $\% \pm 0.59$. Imposed drought stress caused this significant $\delta 13 \mathrm{C}$ variation on the leaf, which is due to the influence of the stomatal conductance and its impact on the fractionation of the stable ${ }^{13} \mathrm{C}$ and ${ }^{12} \mathrm{C}$ isotopes (Farquhar et al. 1982, Delucia et al. 1988). These morphological and ecophysiological responses to drought stress reduced the plant-fixed carbon for plant growth. The photosynthesis processes were not affected by drought stress (Mantovani et al. 2014a), but photorespiration increased under higher air temperature above $30^{\circ} \mathrm{C}$ in the 
Table 6 Mean and standard deviation of leaf nitrogen content, stable isotope ratio $\left(\delta^{15} \mathrm{~N}\right)$, nitrogen derived from the air (NdfA), and of total nitrogen in the aboveground biomass (stem and leaves) of single Robinia pseudoacacia fixed by biological nitrogen fixation, evaluated the experiments in 2011 and 2012

\begin{tabular}{lllllllll}
\hline Treatment & $\begin{array}{l}\text { Leaf } \mathrm{N} \\
\text { content } \\
(\%)\end{array}$ & $\begin{array}{l}\text { sd } \\
(\%)\end{array}$ & $\begin{array}{l}\delta^{15} \mathrm{~N} \\
(\%)\end{array}$ & $\begin{array}{l}\text { sd } \\
(\%)\end{array}$ & $\begin{array}{l}\text { NdfA } \\
(\%)\end{array}$ & $\begin{array}{l}\text { sd } \\
(\%)\end{array}$ & $\begin{array}{l}\text { BNF } \\
\text { total N } \\
\text { fixed } \\
(\mathrm{g})\end{array}$ & $\begin{array}{l}\text { sd } \\
(\mathrm{g})\end{array}$ \\
\hline HW-cost & $2.84^{\mathrm{a}}$ & 0.55 & $-0.82^{\mathrm{a}}$ & 0.87 & $91^{\mathrm{a}}$ & 12 & $23.18^{\mathrm{a}}$ & 5.67 \\
LW-const & $3.22^{\mathrm{a}}$ & 0.66 & $-0.18^{\mathrm{a}}$ & 0.99 & $83^{\mathrm{a}}$ & 16 & $10.47^{\mathrm{b}}$ & 3.05 \\
HW-dc & $2.89^{\mathrm{a}}$ & 0.22 & $0.22^{\mathrm{a}}$ & 0.37 & $76^{\mathrm{a}}$ & 6 & $16.19^{\mathrm{ab}}$ & 2.24 \\
LW-dc & $2.88^{\mathrm{a}}$ & 0.47 & $-0.47 \mathrm{a}$ & 0.36 & $87^{\mathrm{a}}$ & 11 & $12.41^{\mathrm{b}}$ & 1.79 \\
\hline
\end{tabular}

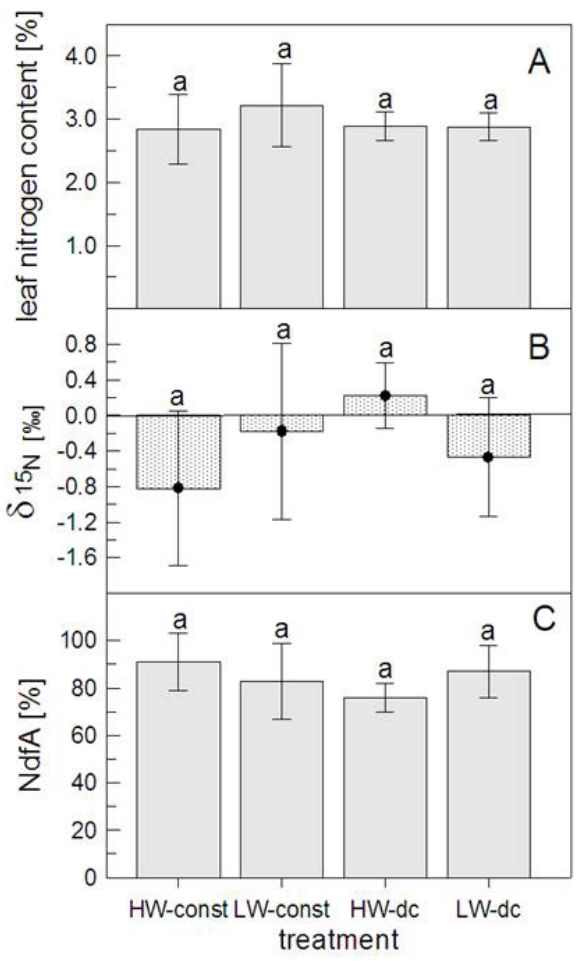

Figure 5 Mean and standard deviation of leaf nitrogen content (A), stable isotope ratio $\left(\delta^{15} \mathrm{~N}\right)(\mathrm{B})$, and nitrogen derived from the air (NdfA) (C) of Robinia pseudoacacia under different watering regimes

(HW-const: high water amounts constant, LW-const low water amounts constant, HW-dc: high water amounts with shortterm drought cycles, LW-dc: low water amounts with long-term drought cycles; see text and Table 1 for details). drought-stressed plants (Veste \& Kriebitzsch 2013), which consequently resulted in a lower net carbon uptake for the trees.

At the whole plant level, the water constraint had a relevant effect on tree growth since the aboveground biomass production is linearly related to the transpired water in both experiments (Mantovani et al. 2014 a,b). The carbon investment in the root system is often not taken into consideration. In mature stands of Robinia approximately $40 \%$ of the dry matter is allocated to the root systems (Quinkenstein et al. 2011) while in short crop rotation the shoot: root ratio depends on the stand age and varies between 0.2 and 3.5 (Quinkenstein et al. 2012). In fact, in our experiment the trees growing under water constraint invested relatively more carbon into the belowground biomass than in shoots and leaves. In various studies it has been observed that carbon allocation into the root system increases under soil water limitation for an optimal carbon partitioning (Larcher 2003, Yin et al. 2005). For European beech (Fagus sylvatica) it was shown that drought stress can stimulate the fine root production (Leuchner et al 2001) which compensates for fine-root mortality and leads to higher root turnover rates (Meier \& Leuschner 2008).

From a physiological viewpoint, we would even expect a drastic impact of drought stress on the biological nitrogen fixation by Robinia as well. Several studies have reported a decrease in the biological nitrogen fixation relat- 


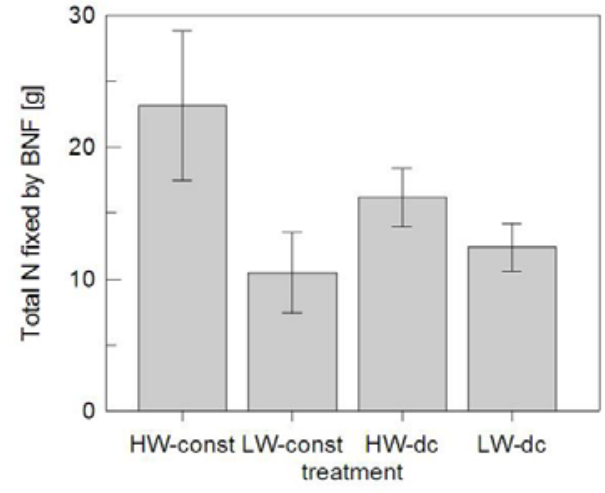

Figure 6 Mean and standard deviation of total nitrogen in the aboveground biomass (stem and leaves) of single Robinia pseudoacacia fixed by biological nitrogen fixation under different watering regimes.

(HW-const: high water amounts constant, LW-const low water amounts constant, HWdc: high water amounts with short-term drought cycles, LW-dc: low water amounts with long-term drought cycles; see text and Table 1 for details).

ed to water constraint in legumes (Kirda et al. 1989, Moro et al.1992, Serraj \& Sinclair 1996, Serraj et al. 1999, Marino et al. 2007). Noh et al. (2010) reported a decrease of nodule production for black locust on dry sites in a field experiment. Under long-term drought stress the leaf nitrogen content of Robinia leaves were slightly reduced (Veste \& Kriebitzsch 2013) and it was assumed that extreme drought influenced $\mathrm{N}$ assimilation and altered the biological nitrogen fixation. On the contrary, in our present study the leaf nitrogen content was rather constant between the irrigation treatments (even under drought stress) and remains at $2.9-3.2 \% \mathrm{~N}$, even during long-term drought stress in the first year. And yet, the relative nitrogen fixed by BNF (expressed as NdfA) was even higher in the second year under drought stress compared to the HW-dc treatment with high irrigation amounts. A reduction of soil $\mathrm{N}$ availability induces nodulation and BNF of nitrogen-fixating trees like Acacia (Cramer et al. 2010) and Robinia (Johnsen \& Bongarten
1991, 1992) in order to sustain the required nitrogen amounts for plant growth. In our experiment the $\delta^{15} \mathrm{~N}$ values of the leaves under drought stress (LW-const, LW-dc) increased as well, which implied a lower relative BNF. On the other hand, the nodule biomass increased. Our observation supports the results of Wurzburger \& Miniat (2013) who found that drought-stressed black locust trees increased nodule biomass by $80 \%$, and investigations by Gray et al. (2013) into field-grown soybeans. These observations were explained by the fact that low soil water content caused an additional reduced soil nitrogen availability for the trees, which was compensated by supplemental BNF (Wurzburger \& Miniat 2013), such as can be observed under low soil nitrogen amounts (Johnsen and Bongarten 1991). However, raising the symbiotic nitrogen fixation increases the carbon costs for the $\mathrm{N}_{2}$ fixation; consequently, photoassimilates are allocated to belowground growth and nodule respiration. The carbon costs of BNF can be higher (approximately $25 \%$ of the daily photosynthesis fixed carbon) compared to nitrogen uptake by non-N-fixing plants growing under optimal $\mathrm{N}$ supply, but these are similar when growing under limited $\mathrm{N}$ conditions (Lambers et al. 2008). Hence, we need also to taken into account the entire nitrogen budget of the trees and its relation to the carbon allocation in the biomass under the different irrigation regimes. In the experiment, the trees were able to maintain the required nitrogen assimilation even under drought stress at the same level as needed for the biomass production. An exception here was the HW-dc treatment trees in the second experiment (2012) when tree growth stopped completely, while the drought-adapted plants (LW-dc) continued to grow even under low soil water availability (Mantovani et al. 2014b). The lower NdfA here indicates a relative reduction of the biological nitrogen fixation compared to the drought-stressed trees, although the absolute fixed nitrogen amount was higher. It can be assumed that the 
observed reduction in the growth of the trees and the lower carbon assimilation due to the short-term drought stress also influence the physiological performance in the nodules. A possible explanation might be a down-regulation of biological nitrogen fixation (including the nitrogenase activity), which is affected by the carbon assimilation of the tree (Gálvez et al. 2005, Ladera et al. 2007, Erice et al. 2014). Under drought stress the carbohydrate supply to the bacteroids decreases and a carbon flux shortage from the shoot to the nodules can affect the metabolism of the symbiotic nitrogen fixation, while at the same time the required nitrogen amount by the plants is reduced.

In fact, the trees growing under low water availability from the beginning and re-sprouted under water constraint in the second year showed high tolerance levels and continued growth when imposed to drought stress during an extreme heat period (Mantovani et al. 2014b). Plants which are pre-conditioned to low water amounts or drought stress seem to be less vulnerable to newly imposed stress (Walter et al. 2011). It has been proposed that they have a memory effect influencing their physiology and growth performance in the following vegetation period (Bréda \& Badeau 2008, Kriebitzsch \& Veste 2012). Moreover, these plants adapted their biomass production to the available water and revealed their nitrogen needs according to the carbon assimilation of the aboveground biomass, but at a reduced level. Our data suggests that Robinia could maintain biological nitrogen fixation (NdfA) at a relatively higher value even under water limitation compared to the well-watered trees. Whether it is the increased nodule biomass (as also described by Wurzburger \& Miniat 2013) or adaption of physiological processes of the Rhizobium strain (Talbi et al. 2012) that contribute to overcoming drought conditions under low but constant water availability is still an open question. However, the carbon fixation, carbon allocation, and biological nitrogen fixation are to some extent balanced and allowed Robinia to cope with long-term water constraint, while short-term drought stress that effects the growth leads to an imbalance between the $\mathrm{C}$ and $\mathrm{N}$ assimilation (Aranjuelo et al. 2013). Even though the trees do not need additional nitrogen fertilizer and show nitrogen fixation (Veste et al. 2013), the application of phosphate can enhance tree growth under extreme edaphic conditions (Kanzler et al. 2015). This example illustrates the complex interaction between carbon and nitrogen metabolisms with other elements. The underlying physiological processes in the nodules and their interactions and regulation in the plant need further investigation. It should however be remarked, that because of the relatively short duration of the experiments, and the high variation of the edaphic conditions chosen, the long-term effect (e.g. 10, 20, 30 years) of water constraint on growth rate and ecophysiological response may vary.

\section{Conclusions}

Even though black locust demonstrated its ability to cope with prolonged drought periods, water limitation had a remarkable effect on $\mathrm{C}$ allocation. As a result the decrease of the shoot:root ratio is to be expected in areas particularly prone to water shortages. Furthermore our study provides evidence supporting the idea that drought stress enhances root nodule production to maintain biological nitrogen fixation and to counteract physiological stress. It explains the ability of Robinia pseudoacacia to grow under extreme edaphic conditions where drought periods affecting tree growth regularly occur in early or late summer. Consequently, black locust has the competitive advantage of higher biomass production on reclaimed sites compared to non-nitrogen fixating trees. These results emphasize the ecological importance of biological fixation under extreme edaphic conditions. 


\section{Acknowledgment}

The research was funded by the International Graduate School of the Brandenburg University of Technology Cottbus-Senftenberg in the form of a Ph.D. grant to the first author.

\section{References}

Aranjuelo I., Tcherkez G., Molero G., Francoise G., Avice J.C., Nogués S., 2013. Concerted changes in N and C primary metabolism in alfalfa (Medicago sativa) under water restriction. Journal of Experimental Botany 64: $1-17$.

Aranjuelo I., Arrese-Igor C., Molero G., 2014. Nodule performance within a changing environmental context. Journal of Plant Physiology 171: 1076-1090.

Batzli J.M., Graves W.R., van Berkum P., 1992. Diversity among Rhizobia effective with Robinia pseudoacacia L. Applied and Environmental Microbiology 58(7): 2137-2143.

Bloom A.J., Chapin F.S., Mooney, H.A., 1985. Resource limitation in plants-an economic analogy. Annual Review of Ecology and Systematics 16: 363-392.

Böhm C., Quinkenstein A., Freese D., 2011. Yield prediction of young black locust (Robinia pseudoacacia L.) plantations for woody biomass production using allometric relations. Annals of Forest Research 54(2): 215-227.

Boddey R.M., Peoples M.B., Palmer B., Dart P.J., 2000. Use of the ${ }^{15} \mathrm{~N}$ natural abundance technique to quantify biological nitrogen fixation by woody perennials. Nutrient Cycling in Agroecosystems 57: 235-270.

Bréda N., Badeau, V., 2008. Forest tree responses to extreme drought and some biotic events : towards a selection according to hazard tolerance? Comptes Rendus Geoscience 340 (9-10): 651-662.

Boring L.R., Swank W.T., 1984. The role of black locust (Robinia pseudoacacia L.) in forest succession. Journal of Ecology 72: 749-766.

Cairns M.A., Brown S., Helmer E.H., Baumgardner G.A., 1997. Root biomass allocation in the world's upland forests. Oecologia 111(1): 1-11.

Cheng X., Zhao Z., Guo M., Wang D., Yuan Z., 2007. A model for vertical distribution of fine roots in Robinia pseudoacacia plantations on the Loess Plateau. Frontiers of Forestry in China 2(3): 291-297.

Cierjacks A., Kowarik I., Joshi J., Hempel S., Ristow M., von der Lippe M., Weber E., 2013. Biological Flora of the British Isles: Robinia pseudoacacia. Journal of Ecology 101 (6): 1623-1640.

Cramer M.D., Van Cauter A., Bond W.J., 2010. Growth of N2-fixing African savanna Acacia species is constrained by below-ground competition with grass. Journal of Ecology 98: 156-167.
Delucia E.H., Schlesinger W.H., Billings W.D., 1988. Water relations and maintenance of Sierra conifers on hydrothermally altered rock. Ecology 69: 303-311.

Dilly O., Nii-Annang S., Schrautzer J., Breuer V., Pfeiffer E.-M., Gerwin W., Schaaf W., Freese D., Veste M. Hüttl, R.F., 2010. Ecosystem manipulation and restoration on the basis of long-term conceptions. In: Müller F., Baessler C., Schubert H., Klotz S. (eds.), Long-term ecological research between theory and application, Springer Science+Business Media, Amsterdam, pp. 411-428.

Enescu C. M., Daşnescu A., 2013. Black locust (Robinia pseudoacacia L.) - an invasive neophyte in the conventional land reclamation flora in Romania. Bulletin of the Transilvania University of Braşov, Series II - Forestry, Wood Industry, Agricultural Food Engineering 6: 2330.

Erice G., Sanz-Sáez A., Aroca R., Ruíz-Lozano J.M., Avice J.-C., Irigoyen J.J., Sanchez-Diaz M., Aranjuelo I., 2014. Photosynthetic down-regulation in $\mathrm{N}_{2}$-fixing alfalfa under elevated $\mathrm{CO}_{2}$ alters rubisco content and decreases nodule metabolism via nitrogenase and tricarboxylic acid cycle. Acta Physiologiae Plantarum 36: 2607-2617.

Farquhar G.D., O’Leary M.H., Berry J.A., 1982. On the relationship between carbon isotope discrimination and the intercellular carbon dioxide concentration in leaves. Functional Plant Biology 9(2): 121-137.

Ferrari A.E., Wall L.G., 2007. Nodulation and growth of black locust (Robinia pseudoacacia L.) on a de-surfaced soil inoculated with a local Rhizobium isolate. Biology and Fertility of Soils 43(4): 471-477.

Gálvez L., González E.M., Arrese-Igor C., 2005. Evidence for carbon flux shortage and strong carbon/nitrogen interactions in pea nodules at early stages of water stress. Journal of Experimental Botany 56: 2551- 2561.

Gao X.F., Wang J.X., Zhang B., Ma H.F., Zhong N., 2010. Effects of drought stress on dry matter partitioning of young Robinia pseudoacacia at its different growth stages. Chinese Journal of Ecology 29: 1103-1108.

Grünewald H., Böhm C., Quinkenstein A., Grundmann P., Eberts J., von Wühlisch G., 2009. Robinia pseudoacacia L.: a lesser known tree species for biomass production. BioEnergy Research 2(3): 123-133.

Gray S.B., Strellner R.S., Puthuval K.K., Ng C., Shulman R.E., Siebers M.H., Rogers A., Leakey, A.D.B., 2013. Minirhizotron imaging reveals that nodulation of fieldgrown soybean is enhanced by free-air $\mathrm{CO}_{2}$ enrichment only when combined with drought stress. Functional Plant Biology 40(2): 137-147

Hoagland, D.R., Arnon D.I., 1950. The water-culture method for growing plants without soil. California Agricultural Experiment Station, Circular 347, University of California, pp. 1-32.

Johnsen K.H., Bongarten B.C., 1991. Allometry of acetylene reduction and nodule growth of Robinia pseudoacacia families subjected to varied root zone nitrate concentrations. Tree Physiology 9: 50-522. 
Johnsen KH, Bongarten B.C., 1992. Relationships between nitrogen fixation and growth in Robinia pseudoacacia L. seedlings: A functional growth analysis approach using ${ }^{15} \mathrm{~N}$. Physiologia Plantarum 85(1): 77-84.

Kanzler M., Böhm C., Freese D., 2015. Impact of P fertilisation on the growth performance of black locust (Robinia pseudoacacia L.) in a lignite post-mining area in Germany. Annals of Forest Research 58(1): 1-16.

Khan B., Ablimit A., Mahmood R., Qasim M., 2010. Robinia pseudoacacia leaves improve soil physical and chemical properties. Journal of Arid Land 2(4): 266271.

Kirda C.S.K.A., Danso S.K.A., Zapata F. 1989. Temporal water stress effects on nodulation, nitrogen accumulation and growth of soybean. Plant and Soil 120 (1): 4955. DOI: 10. 1007/BF02370289.

Kriebitzsch W.-U., Veste M., 2012. Bedeutung trockener Sommer für die Photosynthese und Transpiration von verschiedenen Herkünften der Rotbuche (Fagus sylvatica L.) [Importance of dry summer for photo- synthesis and transpiration of different provenances of beech (Fagus sylvatica L.)]. Landbauforschung 62(4): 193-209.

Küppers M., 1992. Changes in resource-use efficiency in different woody growth forms during secondary forest succession in Central Europe. In: Teller A., Mathy P., Jeffers J.N.R., (eds.). Responses of forest ecosystems to environmental changes, Springer, Heidelberg, pp 628630.

Ladrera R., Marino D., Larrainzar E., González E.M., Arrese-Igor C., 2007. Reduced carbon availability to bacteroids and elevated ureides in nodules, but not in shoots, are involved in the nitrogen fixation response to early drought in soybean. Plant Physiology 145 (2): 539-546.

Lambers H., Chapin III F.S., Pons T.L., 2008. Plant physiological ecology. Springer-Verlag, NewYork. 605 p.

Landgraf D., Wedig S., Klose S., 2005. Medium- and short term available organic matter, microbial biomass, and enzyme activities in soils under Pinus sylvestris L. and Robinia pseudoacacia L. in a sandy soil in NE Saxony, Germany. Journal of Plant Nutrition and Soil Science 168(2): 193-201.

Larcher, W., 2003. Physiological plant ecology. Springer, Heidelberg,, New York, $514 \mathrm{p}$.

Leuschner C., Backes K., Hertel D., Schipka F., Schmitt U., Terborg O., Runge M., 2001. Drought responses at leaf, stem and fine root levels of competitive Fagus sylvatica L. and Quercus petraea (Matt.) Liebl. trees in dry and wet years. Forest Ecology and Management 149: 33-46.

Li P., Zhao Z., Li Z., Xue S., 2011. Root distributions and drought resistance of plantation tree species on the Weibei Loess Plateau in China. African Journal of Agricultural Research 21: 4989-4997.

Linderson M.L., Iritz Z., Lindroth A., 2007. The effect of water availability on stand-level productivity, transpiration, water use efficiency and radiation use efficiency of field-grown willow clones. Biomass and Bioenergy 31(7): 460-468.

Lindroth A., Cienciala E., 1996. Water use efficiency of short-rotation Salix viminalis at leaf, tree and stand scales. Tree Physiology 16 (1-2): 257-262.

López M., Lluch C., 2008. Nitrogen fixation is synchronized with carbon metabolism in Lotus japonicus and Medicago truncatula nodules under salt stress. Journal of Plant Interactions 3 (3): 137-144.

Lopez M.L., Mizota C., Nobori Y., Sasaki T., Yamanaka T., 2014. Temporal changes in nitrogen acquisition of Japanese black pine (Pinus thunbergii) associated with black locust (Robinia pseudoacacia). Journal of Forestry Research 25(3): 585-589.

Mantovani D., Freese D., Veste M., Hüttl R.F., 2011. Modified wick lysimeters for critical water use efficiency evaluation and yield crop modelling. In: Conference proceedings $14^{\text {th }}$ Lysimeter Conference Lysimeters in climate change research and water resources management", pp. 245-248

Mantovani D., Veste, M., Badorreck A., Freese D., 2013. Evaluation of fast growing tree transpiration under different soil moisture regimes using wicked lysimeters. iForest - Journal of Biogeosciences and Forestry 6: 190-200.

Mantovani D., Veste M., Freese D., 2014a. Black locust (Robinia pseudoacacia L.) ecophysiological and morphological adaptations to drought and their consequence on biomass production and water use efficiency. New Zealand Journal of Forestry 44: 29. DOI: 10.1186/ s40490-014-0029-0.

Mantovani D., Veste M., Freese D., 2014b. Effects of drought frequency on growth performance and transpiration of young black locust (Robinia pseudoacacia L.). International Journal of Forestry Research. DOI: 10.1155/2014/ 821891.

Marino D., Frendo P., Ladrera R., Zabalza A., Puppo A., Arrese-Igor C., González E.M., 2007. Nitrogen fixation control under drought stress. Localized or systemic? Plant Physiology 143(4): 1968-1974. DOI: 10.1104/ pp.107.097139.

Malcolm G.M., Bush D.S., Rice S.K., 2008. Soil nitrogen conditions approach pre-invasion levels following restoration of nitrogen-fixing black locust (Robinia pseudoacacia) stands in a pine-oak ecosystem. Restoration Ecology 16 (1): 70-78. DOI: 10.1111/j.1526-100X. 2007.00263.x

Matos E.S., Freese D., Böhm C., Quinkenstein A., Hüttl R.F., 2012. Organic matter dynamics in reclaimed lignite mine soils under Robinia pseudoacacia L. plantations of different ages in Germany. Communications in Soil Science and Plant Analysis 43: 745-755. DOI: 10.1080/ 00103624.2012.648354.

Meier I.C., Leuschner C., 2008. Belowground drought response of European beech: fine root biomass and carbon partitioning in 14 mature stands across a precipitation gradient. Global Change Biology 14: 2081-2095. DOI: $10.1111 /$ j.1365-2486.2008.01634.x. 
Mokany K., Raison R., Prokushkin A.S., 2006. Critical analysis of root:shoot ratios in terrestrial biomes. Global Change Biology 12(1): 84-96. DOI: 10.1111/j.13652486.2005. 001043.x.

Moro MJ, Domingo F, Bermudez-de-Castro, F. 1992. Acetylene reduction activity (ARA) by the shrub legume Adenocarpus decorticans Boiss. in southern Spain (Almeria). Acta Oecologia 13:325-333.

Noh N.J., Son Y., Koo J., Seo K.W., Kim R.H., Lee Y.Y., Yoo K.S., 2010. Comparison of nitrogen fixation for north-and south-facing Robinia pseudoacacia stands in Central Korea. Journal of Plant Biology 53(1): 61-69. DOI: $10.1007 / \mathrm{s} 12374-009-9088-9$.

Olesen P.O., 1971. Water displacement method: a fast and accurate method of determining the green volume of wood samples. Forest Tree Improvement Vol. 3, pp.1-23.

Qiu L., Zhang X., Cheng J., Yin X., 2010. Effects of black locust (Robinia pseudoacacia L.) on soil properties in the loessial gully region of the Loess Plateau, China. Plant and Soil 332 (1-2): 207-217. DOI: 10.1007/ s11104-010-0286-5.

Quinkenstein A., Böhm C., Matos E., Freese D., Hüttl R.F., 2011. Assessing the carbon sequestration in short rotation coppice systems of Robinia pseudoacacia on marginal sites in NE-Germany. In: Kumar B.M., Nair P.K.R. (eds.) Advances in agroforestry: Carbon sequestration potential of agroforestry systems - opportunities and challenges. Springer, Heidelberg, pp. 201-216. DOI: 10.1007/978-94-007-1630-8_11

Quinkenstein A., Pape D., Freese D., Schneider B.U., Hüttl RF., 2012. Biomass, carbon and nitrogen distribution in living woody plant parts of Robinia pseudoacacia L. growing on reclamation sites in the mining region of Lower Lusatia (Northeast Germany). International Journal of Forestry Research. DOI: 10.1155/2012/891798.

Rédei K., Csiha I., Keserü Z., 2011. Black locust (Robinia pseudoacacia L.) short-rotation crops under marginal site conditions. Acta Silvatica et Lignaria Hungarica 7: $125-132$.

Rice S.K., Westerman B., Federici R., 2004. Impacts of the exotic, nitrogen-fixing black locust (Robinia pseudoacacia) on nitrogen cycling in a pine-oak ecosystem. Ecology 174 (1): 97-107. DOI: 10.1023/b:vege.00000 46049.21900.5a.

Russow R., Veste M., Littmann T., 2004. Using the natural ${ }^{15} \mathrm{~N}$-abundance to assess the major nitrogen inputs into the sand dune area of the north-western Negev Desert (Israel). Isotopes in Environmental and Health Studies 40: 57-67. DOI: 10.1080/102560103100 01646554.

Russow R., Veste M., Breckle S.-W., Littmann T., Böhme, F. 2008. Nitrogen input pathways into the sand dunes: biological fixation and atmospheric nitrogen deposition. In: Breckle, S.-W, Yair, A., Veste, M. (eds.), Arid dune ecosystems. Ecological Studies 200, Springer, Berlin Heidelberg New York, pp. 319-336. DOI: 10.1007/9783-540-75498-5_22.

Serraj R., Sinclaīr T.R., Purcell L.C., 1999. Symbiotic
N2 fixation response to drought. Journal of Experimental Botany 50(331): 143-155. DOI: 10.1093/ $\mathrm{jxb} / 50.331 .143$.

Serraj R, Sinclair TR. 1996. Inhibition of nitrogenase activity and nodule oxygen permeability by water deficit. Journal of Experimental Botany 47: 1067-1073. DOI: 10.1093/jxb/47.8.1067.

Schulze E.D., Gebauer G., Ziegler H., Lange O.L., 1991. Estimates of nitrogen fixation by trees on an aridity gradient in Namibia. Oecologia 88(3): 451-455. DOI: $10.1007 /$ BF00317592.

Sukopp H., 2004. Human-caused impact on preserved vegetation. Landscape and Urban Planing 68 (4): 347355. DOI: 10.1016/S0169-2046(03)00152-X.

Talbi C., Sánchez C., Hidalgo-Garcia A., González E.M., Arrese-Igor C., Girard L., Bedmar E.J., Delgado, J. 2012. Enhanced expression of Rhizobium etli cbb3 oxidase improves drought tolerance of common bean symbiotic nitrogen fixation. Journal of Experimental Botany 63,: 5035-5043. DOI: 10.1093/jxb/ers101

Veste M., Böhm C., Quinkenstein A., Freese D., 2013. Biologische Stickstoff-Fixierung der Robinie [Biological nitrogen fixation of black locust]. AFZ-Der Wald 2/2013: 40-42.

Veste M., Kriebitzsch W.U., 2013. Einfluss von Trockenstress auf Photosynthese, Transpiration und Wachstum junger Robinien (Robinia pseudoacacia L.) [Influence of drought stress on photosynthesis, transpiration, and growth of juvenile black locust (Robinia pseudoacacia L.)]. Forstarchiv 84: 35-42.

Vlachodimos K., Papatheodorou E.M., Diamantopoulos J., Monokrousos N., 2013. Assessment of Robinia pseudoacacia cultivations as a restoration strategy for reclaimed mine spoil heaps. Environmental Monitoring and Assessment 185: 6921-6932. DOI: 10.1007/ s10661-013-3075-9.

Wang X., Fang J., Zhu B., 2008. Forest biomass and rootshoot allocation in northeast China. Forest Ecology and Management 255(12): 4007-4020. DOI: 10.1016/ j.foreco.2008.03.055.

Walter J., Nagy L., Hein R., Rascher U., Beierkuhnlein C., Willnerd E., Jentsch A., 2011. Do plants remember drought? Hints towards a drought-memory in grasses. Environmental and Experimental Botany 71(1): 34-40. DOI: $10.1016 /$ j.envexpbot.2010.10.020.

Wurzburger N., Miniat C.F., 2013. Drought enhances symbiotic dinitrogen fixation and competitive ability of a temperate forest tree. Oecologia 174: 1117-1126. DOI: 10.1007/s00442-013-2851-0.

Xu F., Guo W., Wang R., Xu W., Du N., Wang Y. 2009. Leaf movement and photosynthetic plasticity of black locust (Robinia pseudoacacia L.) alleviate stress under different light and water conditions. Acta Physiologiae Plantarum 31(3): 553-563. DOI: 10.1007/s11738-0080265-0.

Yin C., Wang X., Duan B., Luo J., Li C., 2005. Early growth, dry matter allocation and water use efficiency of two sympatric Populus species as affected by wa- 
ter stress. Environmental and Experimental Botany 53: 315-322. DOI: 10.1016/j.envexpbot.2004.04.007.

Zahran H.H., 1999. Rhizobium-legume symbiosis and nitrogen fixation under severe conditions and in an arid climate. Microbiology and Molecular Biology Reviews 63(4): 968-989.
Zeleznik J.D., Skousen J.G., 1996. Land reclamation: survival of three tree species on old reclaimed surface mines in Ohio. Journal of Environmental Quality 25:1429-1435. DOI: $10.2134 /$ jeq1996.0047242500250 $0060037 \mathrm{x}$. 